\title{
PRESIDENT'S POSTSCRIPT- OUR JOURNEY CONTINUES
}

The Materials

Research Society engages members across generations to advance their careers and promote materials research and innovation. f 6 My journey with the Society began when I attended the 1995 MRS Fall Meeting in Boston. I was like a kid in a candy store. I learned so much at that first Meeting that I couldn't wait to go back. Since then, I have attended many more MRS Meetings and slowly evolved from student, to postdoc, to researcher to administrator. Along the way, I took another journey with MRS, and one that I encourage all to try: getting involved with the Society. Today, opportunities for engagement in MRS are many and diverse, and include a broad range of professional development and career services for members from students to seasoned professionals. There are competitions-Science as Art, Science in Video, and the Open Data Challenge. And for innovators, there is $\mathrm{MatSci}$, an opportunity to compete for cash prizes and possible startup funding.

I urge you to get involved with MRS. There are so many ways to engage, to propel the Society into the 22nd century, and to find the right fit for your science journey.

Coming full circle, my excitement for MRS meetings remains. I look forward to many more Fall Meetings in Boston, and particularly look forward to new Spring Meeting adventures in Seattle, Honolulu, and our 'old friend' San Francisco in the years to come! I hope to see you there! $y$

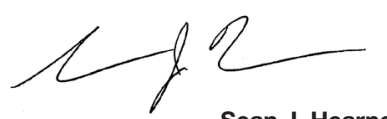
2018 MRS President

\section{$\mathrm{O}_{+}^{+} 14,562$ Members}

\section{$800^{\text {Countries }}$ Represented $49 \%$ non-US}

\section{ชึำ $1100+$ Volunteers}

2

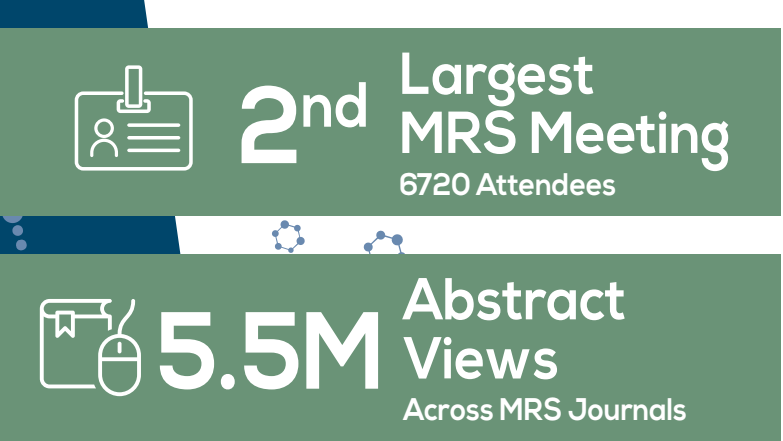

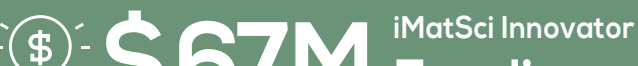 Funding}

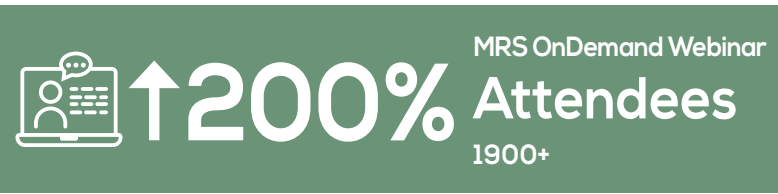

\section{Strange Matter Exhibit $q_{0-0}^{b-q}+0,0$ Visitors 16 Years | 3 Continents}

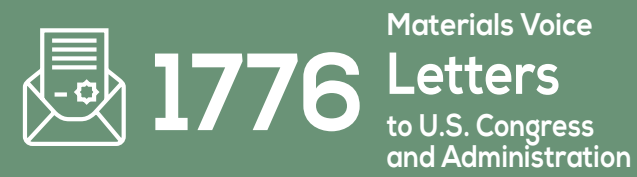




\section{THANK YOU!}

2018 MRS OFFICERS

\section{HIGHLIGHTS}

In 2018, the Society created two new subcommittees-Student Engagement and Early Career Professional Engagementfocused on engaging the next-generation of materials researchers with programs and activities relevant to their needs. Our portfolio of professional development and career services centers on preparing these members for the critical transition from graduate education to the workforce. Salary negotiation, resume writing, and interview and networking skills are just a few examples of our expanded offerings. And in collaboration with four leading scientific societies, MRS is participating in the NSF INCLUDES-funded Inclusive Graduate Education Network (IGEN), created to increase the number of underrepresented ethnic minority students pursuing PhDs in the physical sciences.

Of course, MRS continues to produce highquality meetings and publications, assuring that work germane to the field is timely featured. The growing MRS OnDemand ${ }^{\circledR}$ Webinar Series offers free live and archived content on emerging materials topics by subject experts and global thought leaders, and has now added professional development options. The iMatSci Innovation Showcase has become an increasingly valuable platform for innovators to demonstrate their newest materials-focused technologies. The Journal of Materials Research (JMR) published its third Early Career Scholars in Materials Science issue, providing a unique opportunity for researchers to be highlighted and promoted early in their careers. And the Society named its first recipient of the MRS Nelson "Buck" Robinson Science and Technology Award for Renewable Energy.

This is just a small sampling of the accomplishments MRS and our volunteers realized over the past year ... and it leaves us well positioned for the year to come!

For updated news about programs and opportunities, visit the Materials Research Society at mrs.org.

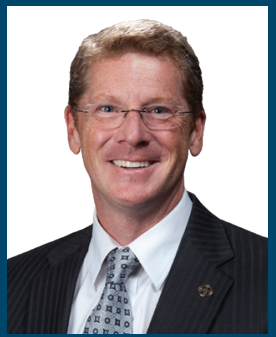

PRESIDENT

Sean J. Hearne

Oak Ridge Nationa Laboratory

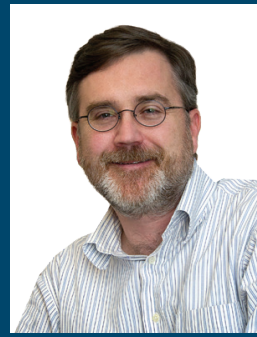

SECRETARY

Eric A. Stach

University of

Pennsylvania

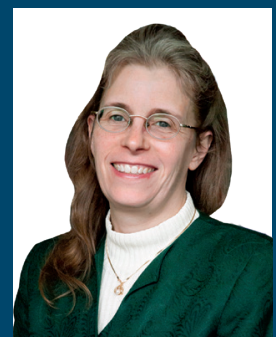

PAST PRESIDENT Susan Trolier-McKinstry The Pennsylvania State University

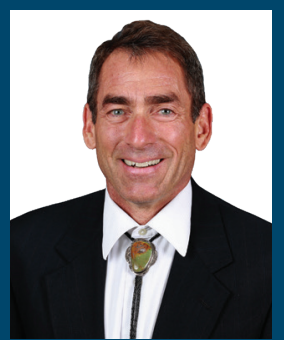

VICE PRESIDENT Michael R. Fitzsimmons Oak Ridge National Laboratory and The University of Tennessee

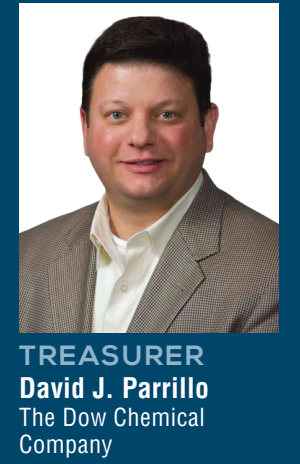

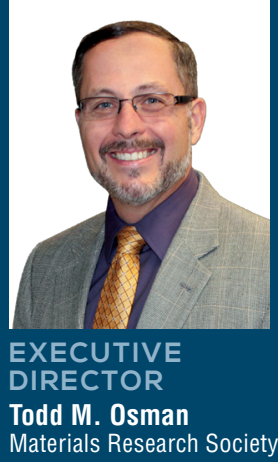

\section{BOARD OF DIRECTORS}

Griselda Bonilla

IBM T.J. Watson Research Center

Li-Chyong Chen

National Taiwan University

Matt Copel

IBM T.J. Watson Research Center

Paul S. Drzaic

Apple, Inc

Dawnielle Farrar-Gaines

Johns Hopkins University

Yury Gogotsi

Drexel University

Claudia Gutiérrez-Wing

Instituto Nacional de

Investigaciones Nucleares (ININ)

Young-Chang Joo

Seoul National University
Lincoln J. Lauhon Northwestern University

Paul C. Melntyre Stanford University

Christopher A. Schuh

Massachusetts Institute of Technology

Rachel A. Segalman University of California, Santa Barbara

Magaly Spector The University of Texas at Dallas Molly M. Stevens Imperial College London

Ehrenfried Zschech

Franhofer Institute for Ceramic Technologies and Systems

\section{OPERATING COMMITTEE CHAIRS}

ACADEMIC AFFAIRS

Sanjay Mathur

University of Cologne

AWARDS

Judith L. MacManus-Driscoll

University of Cambridge

AWARDS

Suveen N. Mathaudhu University of California, Riverside

and Pacific Northwest National Laboratory

GOVERNMENT AFFAIRS

David P. Norton

University of Florida
MEETINGS

Terry Aselage

Sandia National Laboratories

MEMBER ENGAGEMENT

Sossina M. Haile

Northwestern University

PUBLICATIONS

Shefford P. Baker

Cornell University

PUBLIC OUTREACH

Elizabeth Kupp

The Pennsylvania

State University 